\title{
PENGGUNAAN MEDIA SOSIAL SEBAGAI PENUNJANG DALAM PEKULIAHAN ANGGARAN PERUSAHAAN DI PROGRAM STUDI PENDIDIKAN AKUNTANSI
}

\begin{abstract}
Heni Mulyani
ABSTRAK

Penelitian ini bertujuan untuk mengetahui gambaran penggunaan media sosial sebagai penunjang dalam perkuliahan serta dampak yang ditimbulkan dari penggunaan media sosial tersebut dalam perkuliahan mata kuliah anggaran perusahaan di program studi Pendidikan Akuntansi FPEB UPI. Penelitian ini menggunakan metode kuasi eksperimen dengan desain one group only design dengan teknik pengumpulan data yang digunakan adalah obsevasi dengan instrumen lembar pengamatan. Dari hasil penelitian dapat disimpulkan bahwa penggunaan media sosial (khusunya facebook) dapat menjadi penunjang yang efektif dalam proses perkuliahan karena aktivitas belajar bisa dilakukan kapan saja dan dimana saja. Facebook dapat mengatasi permasalahan ruang dan waktu yang terbatas di dalam kelas. Mahasiswa dan dosen dapat melanjutkan interaksi perkuliahan secara online untuk membahas permasalahan terkait materi perkuliahan. Mahasiswa dapat menanyakan dan mengemukakan pendapat serta saling membantu dalam memahami materi perkuliahan. Penggunaan facebook sebagai penunjang dalam perkuliahan akan memberikan dampak yang positif apabila dikelola dengan baik dan diberikan batasan-batasan yang jelas dalam melakukan interaksi, karena dapat memotivasi mahasiswa untuk lebih aktif sehingga mempermudah mereka dalam memahami materi melalui intensitas komunikasi dan interaksi yang dilakukan di luar jam perkuliahan.
\end{abstract}

Kata Kunci : Media Sosial, Penunjang Perkuliahan 


\section{Pendahuluan}

Salah satu perkembangan teknologi dan informasi yang sangat akrab dengan kehidupan para mahasiswa adalah media sosial. Tingkat akses internet didominasi oleh situs-situs jejaring sosial, hal ini disebabkan oleh adanya dukungan dari operator dengan banyaknya perangkat komunikasi yang cerdas dan relatif murah. Penelitian dari Firefly Milward Brown menggambarkan media sosial di Indonesia adalah sebagai alat untuk memperoleh pengakuan secara sosial dalam bentuk pengakuan dan pujian, media sosial juga digunakan untuk berbagi dan mengakrabkan diri dengan orang lain (zdnetasia, 2011).

Pengguna media sosial di Indonesia adalah kedua terbesar di dunia. Sebanyak 35.482 .400 pengguna berasal dari Indonesia dan $85 \%$ pengguna berumur kurang dari 35 tahun., mayoritas berasal dari golongan umur 18-24 tahun dengan jumlah $41 \%$. Umur tersebut merupakan golongan umur pelajar dan mahasiswa. Usia yang sangat potensial untuk mengembangkan kemampuan dan pengetahuan melalui proses pembelajaran.

Media sosial menjadi sebuah ironi, dikarenakan fasilitas yang kerap digunakan justru fasilitas yang tidak begitu bermanfaat atau hanya sekedar just for fun. Pada umumnya yang lebih disukai adalah fasilitas memainkan game, kuis yang tidak jelas tujuan dan manfaatnya, atau sekedar chatting dengan topik yang tidak perlu. Kegiatan seperti ini tentu saja akan banyak membuang waktu dan memboroskan uang saja, terutama bagi remaja-remaja usia sekolah. Dengan adanya perbedaan antara harapan dan kenyataan tersebut, timbullah sebuah kesenjangan.

$\mathrm{Di}$ sisi lain kita berharap perkembangan teknologi akan membantu atau memberikan kemudahan. Tetapi kenyataan di lapangan banyak juga yang menyalah gunakan mdia sosial untuk halhal yang kurang baik. Dari kesenjangan tersebut, langkah apa yang perlu di lakukan seorang pendidik sebagai upaya untuk memberikan pendidikan kepada mahasiswa (Pieter Silitonga, 2012).

Tren pemanfaatan social network ini sebenarnya menjadi peluang yang cukup menarik untuk dimanfaatkan dalam dunia pendidikan sebagai salah satu penunjang dalam proses pembelajaran. Dalam pembelajaran konvensional waktu tatap muka dosen dengan siswa sangat terbatas, tetapi dengan pembelajaran online seperti dengan penggunaan media jejaring sosial ini jarak dan waktu bukan menjadi halangan. Siswa dapat berkomunikasi dengan guru setiap saat dan dimanapun berada (Anonim, 2012).

Proses pembelajaran dapat dilakukan dimana saja dan kapan saja baik secara formal mauapun informal. Pembelajaran dapat dilakukan secara mandiri salah satunya dengan cara mencari informasi yang bisa diperoleh melalui banyak sumber salah satunya adalah internet. Dengan demikian, perlu adanya strategi dalam pembelajaran yang dapat mengakomodasi dan mengarahkan para mahasiswa dalam memanfaatkan kemudahan yang disediakan oleh perkembangan teknologi informasi yang semakin canggih tersebut dan relatif mudah didapat.

Belum lama ini, muncul sebuah media sosial yang dikhususkan untuk digunakan dalam proses pendidikan. Media sosial ini menyediakan ruang bagi mahasiswa dan dosennya untuk melakukan komunikasi dua arah secara online, sehingga perkuliahan tidak hanya dilakukan di dalam ruang kuliah tetapi juga dapat dilakukan di luar ruang kuliah.

Proses perkuliahan melibatkan banyak waktu baik di dalam maupun di luar kampus. Idealnya, perkuliahan dilakukan di dalam ruang kuliah, untuk kemudian mahasiswa melakukan dan melatih kembali materi perkuliahan yang akan atau yang telah dibahas dalam proses perkuliahan. Selama perkuliahan di dalam kelas, mahasiswa dengan mudah melakukan komunikasi dua arah dengan dosen maupun dengan dengan mahasiswa lain, namun saat melakukan tugas dan pendalaman materi diluar ruang kuliah, mahasiswa akan mendapatkan beberapa masalah dalam hal komunikasi untuk menyelesaikan tugasnya.

Berdasarkan penjelasan diatas, maka peneliti merasa perlu untuk mengujicobakan penggunaan media sosial sebagai salah satu penunjang dalam proses perkuliahan, untuk kemudian diperoleh informasi dampak yang dihasilkan dari penggunaan media sosial tersebut dalam perkuliahan.

Tujuan daari penelitian ini adalah untuk menganalisis efektivitas penggunaan media sosial sebagai penunjang dalam perkuliahan dan mengidentifikasi dampak penggunaan media sosial dalam perkuliahan. 


\section{Landasan Teori}

Belajar pada hakikatnya merupakan suatu aktivitas untuk memperoleh perubahan tingkah laku pada dirinya baik potensial maupun aktual, yaitu perubahan secara kognitif, afektif, maupun psikomotorik. Perubahan tersebut terjadi karena usaha sadar yang dilakukan oleh individu yang sedang belajar. Belajar merupakan proses sepanjang hayat dan tidak terbatas pada ruang dan waktu, atau dengan kata lain belajar dapat dilakukan dimana saja dan kapan saja. Sagala (2010 : 12) mengemukakan bahwa "Dalam implementasinya, belajar adalah kegiatan individu dalam memperoleh pengetahuan, perilaku, dan keterampilan dengan cara mengolah bahan belajar".

Didalam proses pembelajaran tidak terlepas dari konsep-konsep ataupun asas (kaidah dasar) yang harus diterapkan oleh guru maupun siswa. Riyanto (2010:62) menjelaskan "Maksudnya adalah bahwa pendidik akan dapat melaksanakan tugasnya dengan baik apabila dapat menerapkan cara mengajar sesuai dengan prinsip-prinsip belajar".

Dimyati dan Mudjiono (2009 : 42-50) mengemukakan bahwa prinsip belajar terdiri dari :
a. Perhatian dan Motivasi
b. Keaktifan
c. Keterlibatan
d. Pengulangan
e. Tantangan
f. Balikan dan Penguatan
g. Perbedaan Individual

Dapat disimpulkan bahwa prinsip belajar berkaitan dengan perhatian dan motivasi, keaktifan, keterlibatan langsung atau pengalaman, pengulangan, tantangan, balikan dan penguatan (law of effect) serta perbedaan individual dimana prinsip tersebut harus dilaksanakan oleh guru maupun siswa demi tercapainya pembelajaran yang efektif.

Pembelajaran yang efektif harus ditunjang dengan media pembelajaran sebagai alat yang mempunyai fungsi menyampaikan pesan (Bovee, 1997). Media merupakan bentuk jamak dari kata "medium" yang berasal dari bahasa latin yang berarti "antara". Istilah media dapat kita artikan sebagai segala sesuatu yang menjadi perantara atau penyampai informasi dari pengirim pesan kepada penerima pesan. Briggs menyebutkan bahwa media adalah segala alat fisik yang dapat menyajikan pesan serta merangsang siswa untuk belajar. Sementara itu Schramm berpendapat bahwa media merupakan teknologi pembawa informasi atau pesan instruksional yang dapat dimanipulasi, dilihat, didengar dan dibaca. Dengan demikian media pembelajaran adalah sebuah alat yang berfungsi untuk menyampaikan pesan pembelajaran (Wisnu Adi Parwatha, 2012).

Media itu bisa berbentuk softwere maupun hardware dan sebagai alat bantu proses belajar mengajar baik di dalam kelas maupun di luar kelas yang berfungsi sebagai menyalurkan pesan yang dapat merangsang pikiran, perasaan, perhatian dan kemauan siswa sehingga dapat mendorong terjadinya proses belajar pada diri siswa (Miftakhul Anwar, 2012).

Media sosial adalah sebuah media online, dengan para penggunanya bisa dengan mudah berpartisipasi, berbagi dan menciptakan isi meliputi blog, jejaring sosial, forum dan dunia virtual. Dalam dunia pendidikan media sosial pun ikut berperan penting dalam peningkatan kualitas pelajar.

Andreas Kaplan dan Michael Haenlein mendefinisikan media sosial sebagai "sebuah kelompok aplikasi berbasis internet yang membangun di atas dasar ideologi dan teknologi Web 2.0 yang memungkinkan penciptaan dan pertukaran user generated content".

Sosial media dipahami sebagai sekelompok jenis media online, yang terbagi atas lima karakteristik (yang dikutip dari tulisan Lester Voit dalam website isnare.articles.com) yaitu :
(1) Partisipasi.
(2) Keterbukaan
(3) Percakapan
(4) Komunitas
(5) Keterhubungan

Ada beberapa keunggulan media sosial antara lain bahwa media sosial merupakan sebuah alat yang dapat digunakan untuk mempublikasikan diri, pekerjaan, pendapat pribadi, kejadian sehari-hari dari diri sendiri. Bagi perusahaan berarti menambah koneksi ataupun pelanggan dan calon pelanggan. Hal ini disebabkan koneksi berarti potensi untuk meraih pembeli dan selanjutnya dapat berarti potensi meningkatnya pendapatan bagi perusahaan. Selain itu perusahaan dapat memperoleh informasi dari demografi mereka. Selain itu juga, kemudahan untuk membuat grup dan membentuk komunitas. 
Dengan media sosial, berkomunikasi secara online dapat dilakukan dengan lebih mudah dan murah daripada harus bertatap muka. Kemudian kolaborasi dan komunikasi antar wilayah, antar benua (lintas batas) dapat dimungkinkan dalam media sosial ini, hal tersebut berarti menghilangkan hambatan-hambatan bagi orang-orang yang ingin berhubungan dengan orang lain, tanpa memperhitungkan hambatan jarak, hambatan waktu, hambatan biaya, hambatan sosial budaya, termasuk hambatan gender dan usia. Salah satu bentuk media sosial adalah situs jejaring sosial, berguna untuk memudahkan pencarian informasi tentang subjek dan objek apapun juga dan dari mana saja. Dengan demikian dapat memberikan konteks dan nilai tambah pengetahuan dan dunia pendidikan. Khusus untuk dunia pendidikan bisa digunakan untuk penerbitan dan berbagi konten.

Selain keunggulan, ada beberapa hal yang perlu diperhatikan terkait kekurangan dari media sosial, yaitu penyalahgunaan media sosial untuk melakukan kejahatan, sebagai contoh pemalsuan identitas untuk penipuan. Akan tetapi, baru-baru ini telah ada peraturan/undang-undang terkait dengan Informasi dan Transaksi Elektronik (ITE) yang sudah menaungi dan proses bisnis dan komunikasi sosial dalam dunia maya, termasuk media sosial ini. Di Indonesia peraturan tersebut adalah Undang-Undang Nomor 11 Tahun 2008 tentang Informasi dan Transaksi Elektronik (ITE).

Selain itu dengan adanya media sosial maka komunikasi dan diskusi akan sangat intens, sehingga bisa saja seseorang larut dalam kebisingan komunikasi itu, dan tidak lagi fokus dalam konteks yang awal didiskusikan.

\section{Kerangka Pemikiran}

Dalam

perkuliahan,

sumber/referensi-nya tidak hanya sekedar berasal dari buku, tetapi juga diperoleh dari interaksi dan komunikasi. Sampai beberapa dekade yang lalu aspek terakhir dari pembelajaran terbatas pada ruang fisik ruang kelas. Namun sekarang, media sosial telah memperluas dimensi dari ruang yang tersedia untuk komponen sosial pembelajaran. Media Sosial dalam pendidikan, menjadi konsep yang relatif baru telah menjadi pusat perhatian banyak pendidik, dosen dan orang tua.

Salah satu media sosial yang dapat digunakan dalam proses pendidikan adalah
Facebook. Facebook telah menjadi bagian dari kehidupan sehari-hari, demikian pula oleh para mahasiswa. Mereka menciptakan kehidupan online yang berbaur dengan dunia offline mereka. Tanggung jawab sebagai dosen untuk membantu mereka lebih memanfaatkan media ini. Seorang dosen sebaiknya mampu mengadaptasi metode dan sesuai dengan perkembangan zaman dan kebutuhan mahasiswa. Penggunaan Facebook di bidang pendidikan merupakan tantangan besar, tetapi tidak terelakkan, kemudian mengubahnya menjadi alat belajar yang hebat bagi para mahasiswa.

\section{METODOLOGI PENELITIAN}

Metode yang digunakan dalam penelitian ini adalah quasi experiment atau eksperimen semu. Menurut Sugiyono (2009:114):

Dalam metode quasi experiment ini memiliki kelompok kontrol, sehingga tidak dapat berfungsi sepenuhnya untuk mengontrol variabel-variabel luar yang mempengaruhi pelaksanaan eksperimen.

Metode ini dikembangkan untuk mengatasi kesulitan dalam menentukan kelompok kontrol dalam penelitian.

Adapun desain penelitian yang digunakan adalah Non equivalent Group Design. Desain ini hampir sama dengan pretest-posttest one group only design, hanya pada desain ini kelompok eksperimen maupun kelompok kontrol tidak dipilih secara random. Desain penelitian tersebut dapat digambarkan seperti tabel berikut ini:

Tabel 1

Desain Penelitian

\begin{tabular}{|c|c|c|c|}
\hline Kelas & $\begin{array}{c}\text { Pre } \\
\text { Test }\end{array}$ & Treatment & $\begin{array}{c}\text { Post } \\
\text { Test }\end{array}$ \\
\hline Eksperimen & $\mathrm{O}_{1}$ & $\mathrm{X}$ & $\mathrm{O}_{2}$ \\
\hline
\end{tabular}

\section{Keterangan}

$\mathrm{O}_{1} \quad$ : Nilai Pretest (sebelum perlakuan) pada kelas eksperimen

$\mathrm{O}_{2} \quad$ : Nilai Posttest (setelah perlakuan) pada kelas eksperimen

$X \quad$ : Perkuliahan dengan

menggunakan media sosial

\section{DESKRIPSI HASIL PENELITIAN}

Sebelum pelaksanaan perkuliahan dengan menggunakan media sosial sebagai penunjangnya, dosen harus 
melaksanakan beberapa tahapan, diantaranya adalah menetapkan bahan ajar, menetapkan rancangan perkuliahan, menetapkan media sosial yang akan digunakan dalam perkuliahan. Dan setelah penyelenggaraan perkuliahan, tahapan terakhir adalah menyiapkan kriteria evaluasi untuk mengukur hasil belajar siswa setelah menerapkan perkuliahan dengan menggunakan media sosial sebagai penunjang dalam proses perkuliahan.

Pada tahapan pertama, dosen harus menetapkan bahan ajar terlebih dahulu, kegiatan dosen diantaranya adalah :

1. Dosen menganalisis silabus pembelajaran dan menentukan materi pembelajaran

2. Dosen menentukan buku sumber yang digunakan dan membuat resume materi perkuliahan sebagai hand out mengenai materi anggaran perusahaan

3. Dosen menyiapkan video pembelajaran yang terkait dengan anggaran penjualan

Setelah menetapkan bahan ajar, tahap kedua dosen menetapkan rancangan perkuliahan dengan menggunakan media sosial. Dalam perkuliahan anggaran perusahaan ini digunakan media sosial yang sangat akrab digunakan oleh semua mahasiswa yaitu facebook.

Selanjutnya, dalam implementasi perkuliahan menggunakan Facebook sebagai penunjang dalam perkuliahan adalah sebagai berikut :

a. Dosen membuat akun facebook dan group facebook, masing-masing siswa harus sudah mempunyai akun facebook.

b. Dosen dalam hal ini harus bertindak sebagai administrator dan memasukkan siswa ke dalam group.

c. Dosen dapat menyediakan materi pembelajaran/tugas melalui fasilitasfasilitas yang sudah disediakan oleh facebook group seperti catatan (note), pada wall, file-file lampiran, gambar dan video.

d. Untuk memberikan tugas yang berbeda pada setiap mahasiswa, dosen dapat melakukannya melalui pesan inbox bisa ditulis langsung atau dalam bentuk lampiran file inbox.

e. Mahasiswa mempelajari materi yang telah diberikan dosen dan dapat memberikan komentar atau pertanyaan melalui fasilitas komentar.

f. Dosen dapat membuka forum diskusi melalui fasilitas-fasilitas yang telah disediakan pada facebook seperti pada fasilitas forum dan bisa juga melalui wall.

g. Banyak aplikasi yang dapat diintegrasikan dengan facebook dan dapat digunakan untuk media pembelajaran seperti Study Groups, CoursFeed dan lain sebagainya

h. Mahasiswa dituntut aktif untuk mencari bahan yang terkait dengan materi pembelajaran dan melakukan sharing dengan temannya.

i. Menindaklanjuti semua kegiatan tersebut dalam pertemuan tatap muka.

j. Evaluasi dilaksanakan dengan tatap muka secara offline

\section{PEMBAHASAN}

Penggunaan Facebook di bidang pendidikan merupakan tantangan besar, tetapi tidak terelakkan, kemudian mengubahnya menjadi alat belajar yang hebat bagi para mahasiswa. Ada beberapa manfaat yang bisa didapatkan dari penggunaan facebook yang efektif antara dosen dengan mahasiswa. Santai, ramah dan mengundang suasana yang mendorong partisipasi dan keterlibatan mahasiswa. Facebook dapat meningkatkan kerjasama dan interaksi sosial antara mahasiswa. Mahasiswa merasa nyaman belajar melalui Facebook karena kebanyakan dari mereka menggunakannya sehari-hari. Mahasiswa merasa terus terlibat untuk belajar meskipun di luar kelas.

Beberapa cara menggunakan Facebook untuk tujuan pendidikan seperti untuk membuat grup untuk kelas dan memperkuat komunikasi antara dosen dengan mahasiswa, menjadwalkan acara untuk seluruh kelas, menggunakan utilitas pesan di Facebook untuk pesan absen tak terduga, penjadwalan ulang ujian, berbagi konten pembelajaran multimedia seperti video, foto, klip dan banyak lagi dengan seluruh kelas, mem-posting catatan kelas bagi mahasiswa untuk review bahan ajaran dalam kasus mereka tidak hadir, membagi konten online dengan mahasiswa seperti website yang menarik, blog, wiki, dan banyak lagi, serta menggunakan event di facebook untuk mengingatkan mahasiswa mengenai kunjungan lapangan mendatang. Dan masih banyak lagi yang dapat dilakukan dengan aplikasi ini. 
Sebelum menggunakan facebook sebagai penunjang dalam perkuliahan, dosen membuat account terpisah hanya untuk kelas, mengelola pengaturan privasi untuk menjaga kehidupan profesional dan pribadi terpisah. Dosen membentuk sebuah kelompok kelas privat untuk berkomunikasi dengan mahasiswa. Dosen memberikan instruksi yang jelas kepada mahasiswa mengenai hal apa saja yang boleh dan tidak boleh di-share di Facebook. Dosen harus rajin mengawasi jenis foto apa yang boleh di-share di Facebook. Dosen harus mengajarkan mahasiswa tentang etika berinternet Selanjutnya jangan menambahkan mahasiswa sebagai teman di account pribadi dan selalu jaga jarak, jangan terlibat dalam kehidupan pribadi mahasiswa dan tidak boleh ada mahasiswa yang harus dipaksakan untuk menambah satu sama lain sebagai teman. Di lain pihak mahasiswa tidak diperbolehkan memposting ancaman, bahan rasis, atau pencemaran nama baik dan selalu libatkan mahasiswa dalam perdebatan yang baik dan terhormat. Ingatkan mahasiswa untuk bertanggung jawab sendiri secara online. Mahasiswa wajib berbuat lebih baik ketika berkomunikasi dalam dunia maya dan merasa bertanggung jawab untuk pembelajaran mereka. Gunakan pengaturan privasi secara fleksibel di Facebook untuk memilih siapa yang dapat melihat apa yang di halaman profil; serta yang terakhir sangat diharapkan dosen akan selalu tetap terlibat.

Perkuliahan berlangsung melalui pertemuan tatap muka di kelas antara dsen dan mahasiswa. Sebelum pertemuan tatap muka di kelas, dosen sudah terlebih dahulu memposting bahan perkuliahan di facebook supaya dapat dipelajari oleh mahasiswa. Setelah setiap pertemuan atap muka di kelas selesai dilaksanakan, mahasiswa dan dosen dapat melanjutkan ineraksi perkuliahan dengan menggunakan facebook, yaitu untuk membahas kesulitan yang diaami oleh mahasiswa dalam mengerjakan tugas perkuliahan.

Interaksi yang terjadi lebih banyak pada membahas kesulitan dalam menyelesaikan tugas yang diberikan. Komunikasi antar dosen dan mahasiswa serta antar mahasiswa dengan mahasiswa berjalan dengan menyenangkan, walaupun pada awalnya tidak semua mahasiswa ikut terlibat dalam berdiskusi. Dosen tdak dapat setiap saat melakukan percakapan online sehingga terkadang mahasiswa melakukan diskusi antar mahasiswa saja, tetapi dosen dapat melakukan pemantauan kapan saja terhadap aktivitas yang dilakukan mahasiswa.

Jika digunakan dengan baik, facebook dapat menjadi penunjang yang efektif dalam proses perkuliahan karena aktivitas belajar bisa dilakukan kapan saja dan dimana saja. Facebook dapat mengatasi permasalahan ruang dan waktu yang terbatas di dalam kelas. Mahasiswa dan dosen dapat melanjutkan interaksi perkuliahan secara online untuk membahas permasalahan terkait materi perkuliahan. Mahasiswa dapat menanyakan dan mengemukakan pendapat serta saling membantu dalam memahami materi perkuliahan.

Dari hasil eksperimen yang telah dilakukan, dapat diketahui kelebihan facebook apabila digunakan sebagai penunjang dalam perkuliahan :

a. Tidak tergantung pada ruang dan waktu dimanapun kapanpun proses pembelajaran dapat berlangsung.

b. Mudah mendapatkan bahan/informasi yang berhubungan dengan materi pembelajaran.

c. Facebook adalah situs pertemanan yang banyak diminati oleh remaja usia sekolah sehingga kita bisa mengarahkan mereka untuk menggunakan facebook pada hal-hal yang lebih bermanfaat seperti menggunakannya sebagai media pembelajaran.

d. Ada kalangan tertentu yang memandang negatif facebook sehingga dengan memanfaatkan facebook dalam pembelajaran dapat membuktikan bahwa facebook juga dapat dimanfaatkan pada hal-hal yang lebih berguna.

e. Dapat mengurangi dampak negatif dari facebook akibat penggunaannya pada hal-hal yang negatif seperti saling ejek, penipuan, dan lain sebagainya.

f. Dapat membimbing siswa secara lebih intensif.

g. Banyak aplikasi yang dapat diintegrasikan dengan facebook dan dapat digunakan untuk media pembelajaran seperti Study Groups, CoursFeed dan lain sebagainya.

Sedangkan kelemahan Facebook

sebagai penunjang dalam perkuiahan adalah sebagai berikut :

a. Meskipun facebook dapat diakses melalui HP tetapi pembelajaran dengan facebook baru bisa efektif jika menggunakan 
komputer/Laptop

sehingga

memberikan keleluasaan sehingga mengharuskan semua siswa memiliki komputer/laptop.

b. Perlu dukungan akses internet, sehingga memerlukan biaya untuk akses internet.

c. Sulit membuat siswa untuk konsentrasi pada materi pembelajaran, karena ada banyak hal lain yang tidak ada hubungannya dengan pembelajaran lebih menarik perhatian siswa.

Penggunaan media sosial khusunya facebook sebagai penunjang dalam perkuliahan dapat membantu mahasiswa untuk dapat berinteraksi lebih sering dan terbuka di luar jam perkuliahan untuk membahas materi perkuliahan yang belum dipahami dan sharing pendapat mengenai kesulitan yang dihadapi dalam perkuliahan.

Penggunaan facebook sebagai penunjang dalam perkuliahan akan memberikan dampak yang positif apabila dikelola dengan baik dan diberikan batasan-batasan yang jelas dalam melakukan interaksi, karena dapat memotivasi mahasiswa untuk lebih aktif sehingga mempermudah mereka dalam memahami materi melalui intensitas komunikasi dan interaksi yang dilakukan di luar jam perkuliahan.

\section{KESIMPULAN}

Berdasarkan hasil penelitian yang telah dilakukan, maka dapat diambil beberapa kesimpulan berikut ini :

1. Penggunaan media sosial (khususnya facebook) dapat menjadi penunjang yang efektif dalam proses perkuliahan karena aktivitas belajar bisa dilakukan kapan saja dan dimana saja. Facebook dapat mengatasi permasalahan ruang dan waktu yang terbatas di dalam kelas. Mahasiswa dan dosen dapat melanjutkan interaksi perkuliahan secara online untuk membahas permasalahan terkait materi perkuliahan. Mahasiswa dapat menanyakan dan mengemukakan pendapat serta saling membantu dalam memahami materi perkuliahan.

2. Penggunaan facebook sebagai penunjang dalam perkuliahan akan memberikan dampak yang positif apabila dikelola dengan baik dan diberikan batasan-batasan yang jelas dalam melakukan interaksi, karena dapat memotivasi mahasiswa untuk lebih aktif sehingga mempermudah mereka dalam memahami materi melalui intensitas komunikasi dan interaksi yang dilakukan di luar jam perkuliahan.

\section{SARAN}

Dari hasil penelitian yang telah dilakukan dapat diberikan beberapa saran, sebagai berikut :

1. Media sosial (facebook) dapat digunakan sebagai penunjang dalam perkuliahan untuk membantu memfasilitasi mahasiswa dalam memahami materi dan mengatasi kesulitan yang dihadapi dalam pengerjaan tugas di luar jam perkuliahan.

2. Mencoba untuk menggunakan media sosial lainnya (selain facebook) sebagai penunjang dalam perkuliahan.

\section{REFERENSI}

Anonim. (2012). Pembelajaran Dengan Facebook.

Anonim. (2010). Kajian Model Konseptual Materi e-Pembelajaran, Laporan Akhir

Furqon, (2008), Statistik Terapan untuk Penelitian. Bandung : Alphabeta

Ganisa, A. Kelebihan dan Kekurangan Facebook, Twitter, dan Google Plus, http://informatika.blogspot.com/2011/ 12/kelebihan-dan-kekuranganfacebook.html, diakses tanggal 1 September 2014.

Kaplan, A dan Haenlein, M. Media sosial. http://id.wikipedia.org/wiki/Media sos ial, diakses 5 September 2014

Lester Voit, Participation, Openness, Coversation, Community, Connectedness. Yes, That Whats Social Media is all Media About, http://www.isnare.com/?aid=595202 \&ca=Marketing, diakses tanggal 5 September 2014

Mayfield, A. What is Social Media. http://www. icrossing.co.uk/fileadmin/ uploads/eBooks/What_is_Social_Me dia_iCrossing_ebook.p̄df, diakses tanggal 4 September 2014 
Mardiyah, R. Manfaat Jejaring Sosial Untuk Pendidikan,

http://rifamardiyah.blogspot.com/201

3/07/manfaatmedia-sosial-

dalamdunia_10.html, diakses tanggal 1 September 2014

Mc Leod Jr., R. \& Schell, G. 2008. Sistem Informasi Manajemen, Edisi ke-10, Edisi Penerbit Salemba Empat.

Nurhakim, N. Kelebihan dan Kekurangan Facebook, http://nurmannurhakim. blogspot.com/2010/05/kelebihandan-kekurangan-facebook.html, diakses 4 September 2014

O'Brien, M. (2009). Management Information Systems, McGraw Hill International Edition, Ninth Edition

Pieter Silitonga, 2012. Hindari Dampak Negatif Facebook dengan

Menjadikannya Sebagai Media

Pembelajaran,

piterbizz.blokspot.com

Riduwan. (2011). Dasar-Dasar Statistika. Bandung : Alfabeta

Renata. 2012. Pembelajaran Bebasis

Facebook,www.wordpress.com

Sugiyono. (2009). Metode Penelitian Pendidikan. Bandung : CV. Alfabeta (2011). Statistika Untuk Penelitian. Bandung : CV. Alfabeta

Sutarno. (2012). Pembelajaran Berbasis Facebook. www.formulasi.or.id

Tejo Nurseto. (2011). Membuat Media Pembelajran Yang Menarik, Jurnal Ekonomi \& Pendidikan, Volume 8 Nomor 1, April 2011

Wisnu Adi Parwatha, 2012. Optimalisasi Facebook Sebagai Media Pembelajaran. Program Studi Bahasa Inggris Fakultas Keguruan dan IImu Pendidikan Universitas Mahasaraswati, Denpasar.

Wikipedia, 2012. Sejarah Facebook. www.wikipedia.org. 